\title{
Growth and energetics of the sponge Halichondria panicea
}

\author{
Søren Thomassen, Hans Ulrik Riisgård* \\ Institute of Biology, Odense University, DK-5230 Odense M, Denmark
}

\begin{abstract}
The filtration rate $\left(F, \mathrm{ml} \mathrm{min}^{-1}\right.$ measured as clearance of algal cells $)$ and maintenance respiration rate $\left(R_{\mathrm{m}}, \mathrm{ml} \mathrm{O} \mathrm{O}_{2} \mathrm{~h}^{-1}\right.$ measured as starvation respiration rate) as a function of Halichondria panicea colony size (dry weight DW, g) were described by: $F=28.35 \mathrm{DW}^{0.914}$ and $R_{\mathrm{m}}=0.632 \mathrm{DW}^{0.927}$, respectively. At the maximum specific growth rate of $4 \% \mathrm{~d}^{-1}$ the net growth efficiency was about $30 \%$. The specific respiration rate $\left(R_{s}\right)$ as a function of the specific growth rate $(\mu)$ was described by the equation: $R_{5}=n \mu+\alpha$ where $n$ is the energy cost per unit of growth and $a$ is $R_{\mathrm{s}}$ at zero growth rate. It was found that the energy cost of growth constituted $139 \%$ of the biomass increase. This showed that sponges apparently have a higher energy demand for growth than other invertebrates. When sponge colonies were transferred to filtered sea water, a near linear decrease of chlorophyll a (chl a) was seen during the first $24 \mathrm{~h}$. A similar decrease was observed in sponges transferred directly from the field to filtered sea water. The reduction constants $(r)$ in the 2 cases were 3.3 and $2.8 \% \mathrm{~h}^{-1}$, respectively. The estimated filtration rates, using the equation $F_{\text {esl }}=(r \times S) / \mathrm{chl} a_{\text {, where }} S$ is the steady-state chl a content, were almost identical to filtration rates measured as clearance. It is stressed that sponges have a low water pumping capacity compared with other filter-feeding invertebrates, but compensate for this by a high retention efficiency for small particles $>0.1 \mu \mathrm{m}$.
\end{abstract}

KEY WORDS: Filtration rate - Respiration rate . Energy cost of growth - Net growth efficiency Suspension feeding

\section{INTRODUCTION}

A considerable controversy exists about the relation of sponges to other invertebrate groups (Simpson 1984). Sponges are simple, multicellular animals with tissues but no distinct organs. They feed by extracting suspended food particles from the surrounding water using flagellated cells (choanocytes) and the entire body is specialized for this purpose. The structure of the choanocytes, which constitutes the basic pumping and filtering elements, is the same in all sponges. The choanocytes are structurally and functionally identical to the choanoflagellates that filter free-living bacteria in the sea (Fenchel 1982). The striking similarity between choanoflagellates and choanocytes has given rise to the assumption that sponges have evolved from choanoflagellates (e.g. Barnes 1987, Larsen \& Riisgård 1994)

-Addressee for correspondence. E-mail: fjordlab@dou.dk
To investigate the possible relationship between sponges and choanoflagellates it is important to compare similarities and differences. One crucial difference between sponges and choanoflagellates is the ability of the former to feed on phytoplankton which is retained and digested (phagocytosis) in the extensive inhalant channel system (e.g. Killian 1952, Simpson 1984) before the water is finally filtered through the $0.1 \mu \mathrm{m}$ collar slits of the choanocytes. Few workers seem to have focused on the differences in the physiological performances that may exist between sponges and other filter-feeding invertebrates. All living major sponge groups had representatives in the Cambrian period, about 600 million years ago, but since then sponges have undergone no major evolutionary changes (Bergquist 1978). Ecophysiological investigations of sponges are few and many questions dealing with their interactions with the environment remain largely unanswered. Therefore, it is interesting to carry out comparative ecophysiological studies that 
may uncover the nature of sponges and their relationship with other invertebrates as well as with choanoflagellates.

In this study we dealt with key ecophysiological parameters to obtain a deeper understanding of the adaptation of sponges to suspension feeding. This was done through field and laboratory studies of the energy cost of growth as related to the water processing ability of the demosponge Halichondria panicea. This information enabled us to compare sponges with more advanced filter-feeding invertebrates.

\section{MATERIALS AND METHODS}

Collection and storage of sponges. The experiments were performed on the demosponge Halichondria panicea which during 1994 was gently collected by hand from the surface of boulders at 0.5 to $1 \mathrm{~m}$ water depth at low tide in the inlet to Kerteminde Fjord, Funen, Denmark. The sponges, always kept submerged throughout manipulation, were transported to the nearby Fjord Biological Laboratory, Kerteminde, where the $H$. panicea colonies were individually suspended on $10 \mathrm{~cm}$ long nylon threads in an aquarium with a continuous flow of sea water from the collecting site (11 to $14^{\circ} \mathrm{C}, 11$ to $24 \% \mathrm{~S}$ ). This protocol ensured that the sponge colonies would remain in good condition until experimental measurements were performed.

Measurement of filtration rate. Filtration rates were measured as the volume of water cleared per unit of time (clearance) of the flagellate Rhodomonas sp. from a continuous culture. Flagellate cells with a mean diameter of about $6.3 \mu \mathrm{m}$ are retained by the sponges with $100 \%$ efficiency (Reiswig 1971), and therefore, the measured clearance is identical to the filtration rate (= pumping rate). 2 to $3 \mathrm{~h}$ prior to each clearance experiment the individual sponge colonies were suspended in the centre of a $1 \mathrm{l}$ glass beaker containing $800 \mathrm{ml}$ strongly aerated sea water and placed in a temperature-constant water bath $\left(14^{\circ} \mathrm{C}\right)$. Flagellate cells were added (usually about $5 \times 10^{3}$ cells $\mathrm{ml}^{-1}$ ) and the reduction in the number of cells as a function of time was followed by removing water samples every $10 \mathrm{~min}$. The particle concentration of each sample was measured with an electronic particle counter (Elzone 180 fitted with a $60 \mu \mathrm{m}$ tube) as the mean value of 3 measurements, each using $0.25 \mathrm{ml}$ of the sample. The remainder of the sample was returned to the beaker to avoid a significant reduction in sea water volume $\left(V_{s w}\right)$ during the experiment. A beaker without a sponge colony served as a control. Clearance $(F)$ was determined from the exponential reduction in algal cell concentration as a function of time (verified as a straight regression line of a semilog plot) using the formula:

$$
F=\left(V_{\text {sw }} / t\right) \ln \left(C_{0} / C_{t}\right)
$$

where $C_{0}$ and $C_{t}$ are the algal concentrations at time 0 and time $t$, respectively.

Measurement of respiration rate. The sponges were transferred to an adjustable respiration chamber consisting of straight plexiglass tubes with either 1000, 250 or $170 \mathrm{ml}$, depending on the size of the sponge colony. All measurements were made approximately $1 \mathrm{~h}$ after transfer to the respiration chamber. The respiration chamber consisted of a plexiglass tube (inner diameter $=60 \mathrm{~mm}$ ) with one (adjustable) end closed and the other end tightened with a plexiglass collar with an oxygen electrode mserted into the chamber and connected to an oxygen monitor (WTW, Microprocessor based oximeter, OXI 196) and a recorder (Servogor S). A magnetic stirrer (Oximeter-RZ 90) was mounted close to the membrane of the electrode and coupled to an external rotating magnet. The temperature was held constant $\left(14^{\circ} \mathrm{C}\right)$ by placing the respiration chamber in a water bath. All measurements were conducted at 18 to $23 \%$ S. During each respiration measurement (20 to $30 \mathrm{~min}$ ) the decreasing dissolved oxygen tension was continously monitored. Three respiration measurements were carried out in series on each sponge colony. Control measurements without sponges were performed between every second respiration measurement. The oxygen uptake rate was calculated from the decrease of dissolved oxygen tension, taking temperature, salinity and air pressure into consideration.

Growth experiments. Laboratory growth experiments: Sponge colonies were allowed to adjust to the laboratory conditions for $45 \mathrm{~d}$ after being collected in May 1994. In 5 aquaria (20 l) with a filtered (by means of the mussel Mytilus edulis) flow of sea water $\left(19^{\circ} \mathrm{C}\right.$, 13 to $17 \% \mathrm{~S}$, mean water residence time was $50 \mathrm{~min}$ ) 6 sponges were suspended as described above. The flagellate Rhodomonas sp. from a continous culture (constant light, $\mathrm{pH}$ and dilution rate) was used in the growth experiments with Halichondria panicea. Algal concentrations of $0,2.7,3.6,5$ and $7 \times 10^{3}$ cells $\mathrm{ml}^{-1}$ were maintained in the growth aquaria by continous addition of Rhodomonas cells. After an adjustment period of $4 \mathrm{~d}$ (Day 0) the 'drip wet weight' (DWW) of the sponges was measured. Subsequently the sponge colonies were weighed again on Day 9 to assess the growth. Throughout the experimental period the algal concentrations in the growth aquaria were checked twice a day.

Field growth experiments: In situ growth experiments with sponge colonies were performed by means of a 'sponge-anchor' arrangement consisting of a $10 \mathrm{~kg}$ concrete anchor with 10 plastic sticks fixing the sponge colonies mounted on a plate (see Fig. 1). After $1 \mathrm{wk}$ in 


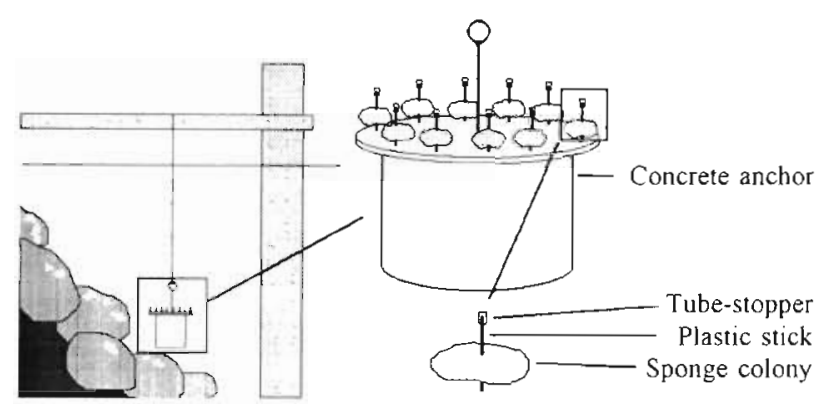

Fig. 1. Halichondria panicea. 'Sponge-anchor' used for in situ growth experiments with sponge colonies is submerged $1 \mathrm{~m}$ below the water surface; white patches on the boulders illustrate natural sponge colonies

a flow aquarium with sea water the sponge colonies were placed near the collecting site in the inlet to Kerteminde Fjord, slightly raised above the stones with the natural sponge colonies (see Fig. 1). Four growth experiments (duration of 1 to $3 \mathrm{wk}$ ) each with 10 sponge colonies were performed. The transplanted sponges were checked daily for drifting pieces of macrophytes and cleaned if necessary, and a water sample (5 I filtered through a $40 \mu \mathrm{m}$ sieve to remove particles larger than the sponge's ostia) for measurement of chlorophyll a (chl a) (according to Arvola 1981) was taken. At the end of the growth experiment the respiration rate and size of each sponge colony was measured.

Specific reduction and energetic parameters. The specific growth rate $\left(\mu, \mathrm{d}^{-1}\right)$ of Halichondria panicea was calculated according to the equation:

$$
\mu=\ln \left(W_{t} / W_{0}\right) t^{-1}
$$

where $W_{0}$ and $W_{t}=$ mean body mass of the sponges on Day 0 and Day $t$, respectively.

By simultaneous measurements of respiration and growth rates in animals with body mass $W$ the relationship between total respiration rate $\left(R_{t}\right)$ and growth rate $(\mu W)$ may be described according to Kiørboe et al. (1987): $R_{\mathrm{t}}=R_{\mathrm{m}}+n \mu W$ or

$$
R_{1} / W^{b}=a+n \mu W^{1-b}
$$

where $R_{\mathrm{m}}=a W^{b}$ is the maintenance respiration rate (measured as starvation respiration rate) and the energy cost per unit of growth is $n$, which was estimated from experimentally determined values of $R_{\mathrm{m}}$, $R_{\mathrm{t}}$ and $\mu$ (i.e. slope of regression line for $R_{\mathrm{t}} / W^{b}$ as a function of $\left.\mu W^{1-b}\right)$.

The energy balance of a sponge colony can be expressed as:

$$
I=P+R+E
$$

where $I=$ ingestion, $P=$ production (growth), $R=$ respiration, and $E=$ excretion. Further, the assimilation is
$A=P+R$, and the net growth efficiency is $\mathrm{NGE}=P / A$ In the present work NGE was calculated according to:

$\mathrm{NGE}=P / A=P /(P+R)=W_{\mu} /(W \mu+R)=\mu /\left(\mu+R_{\mathrm{s}}\right)$

where $R_{\mathrm{s}}=R / W$.

Chlorophyll decomposition and estimation of filtration rate. Two parallel experiments were performed to measure the chl a decomposition rate in sponge colonies in order to estimate the in situ filtration rate of the sponges. At steady state: $I=r \times S$, where $I$ is the ingestion rate, $r$ is the chl a decomposition constant and $S$ is the chl a content in the sponge. When the chl a concentration in the sea water surrounding the sponge (chl a) is known, the in situ filtration rate $\left(F_{\text {est }}\right)$ can be estimated as $F_{\text {est }}=I / \mathrm{chl}$ a or:

$$
F_{\text {est }}=(r \times S) / \mathrm{chl} a
$$

In the laboratory the filtration rates of 20 sponge colonies were determined previous to exposure to a constant algal concentration of $4 \times 10^{3}$ Rhodomonas cells $\mathrm{ml}^{-1}$ in an aquarium with filtered $(0.7 \mu \mathrm{m})$ sea water which was changed daily. After 24 and $48 \mathrm{~h}$, respectively, 6 pieces of sponge-tissue $(0.5$ to $1.5 \mathrm{ml})$ were cut off for determination of chl a content. Then the algal supply to the sponges was stopped, and the subsequent reduction in the sponge tissue of chl a was followed by chlorophyll analysis at $6,12,18$, $24,36,48$ and $72 \mathrm{~h}$. An identical experiment was performed with freshly collected sponges from the field.

Determination of sponge size. After the experiments, the sizes of the individual sponge colonies were expressed in several ways: 'drip wet weight' (DWW, determined as the total weight of the sponge colony, including water, added to a known amount of water; cf. Frost \& Williamson 1980); wet weight (WW, total weight of sponge colony after $5 \mathrm{~min}$ drainage on absorbing paper); volume ( $V_{\text {displ, }} \mathrm{ml}$ of displaced water in a graduated cylinder glass); dry weight (DW, $100^{\circ} \mathrm{C}$, $24 \mathrm{~h}$ ); and ash free dry weight (AFDW, $6 \mathrm{~h}$ ashing of ground DW samples in a muffle furnace at $500^{\circ} \mathrm{C}$ ). Sample weights were determined on a Mettler ME22 microbalance

Conversion factors. DW $(g)$, WW $(g)$ and AFDW $(g)$ of Halichondria panicea were found to correlate with sponge colony volume $\left(V_{\mathrm{sc}}\right)$ according to the equations: $\mathrm{DW}=0.07 V_{\mathrm{sc}}\left(\mathrm{r}^{2}=0.984\right), \mathrm{WW}=0.830 V_{\mathrm{sc}}\left(\mathrm{r}^{2}=0.950\right)$ and AFDW $=0.024 V_{\mathrm{sc}}\left(\mathrm{r}^{2}=0.975\right)(\mathrm{n}=20$; range 1 to $80 \mathrm{ml}$. Further, DW and AFDW were found to correlate with the sponge DWW (g) according to the equations: $\mathrm{DW}=0.067 \mathrm{DWW}\left(\mathrm{r}^{2}=0.994\right)$ and $\mathrm{AFDW}=$ $0.023 \mathrm{DWW}\left(\mathrm{r}^{2}=0.972\right)(\mathrm{n}=20$; range 1 to $90 \mathrm{~g})$. The carbon (C) and nitrogen ( $\mathrm{N}$ ) contents were analysed in 20 sponge colonies (Carlo Erba EA1108 CHNS-analyzer with Euger 200 software) and the following 
equivalencies were estimated: $1 \mathrm{mg}$ DW sponge corresponding to $0.142 \pm 0.018 \mathrm{mg} \mathrm{C}$ and $0.030 \pm 0.008 \mathrm{mg}$ $\mathrm{N}_{i} 1 \mathrm{ml} \mathrm{O}_{2}$ corresponding to $0.46 \mathrm{mg} \mathrm{C}$ (Jørgensen 1955 cited by Stuart \& Klumpp 1984); $1 \mathrm{mg}$ chl a corresponding to $40 \mathrm{mg} \mathrm{C}$.

\section{RESULTS}

Filtration rate and respiration rate of Halichondria panicea as a function of sponge colony size are shown in Fig. 2. It is notable that the exponents $(b)$ of both equations are near identical ( $b=0.914$ and 0.927 , respectively) and not significantly different from $1(\mathrm{p}<0.005)$.

Fig. 3 shows the net growth efficiency as a function of specific growth rate of Halichondria panicea in laboratory and in field studies. The maximum measured growth rate was about $4 \% \mathrm{~d}^{-1}$ at a net growth efficiency of about $30 \%$.

In the present work $b \approx 1$ (cf. Fig. 2), and Eq. (3) simplifies to $R_{\mathrm{s}}=n \mu+a$. In Fig. 4 it appears that the rela-
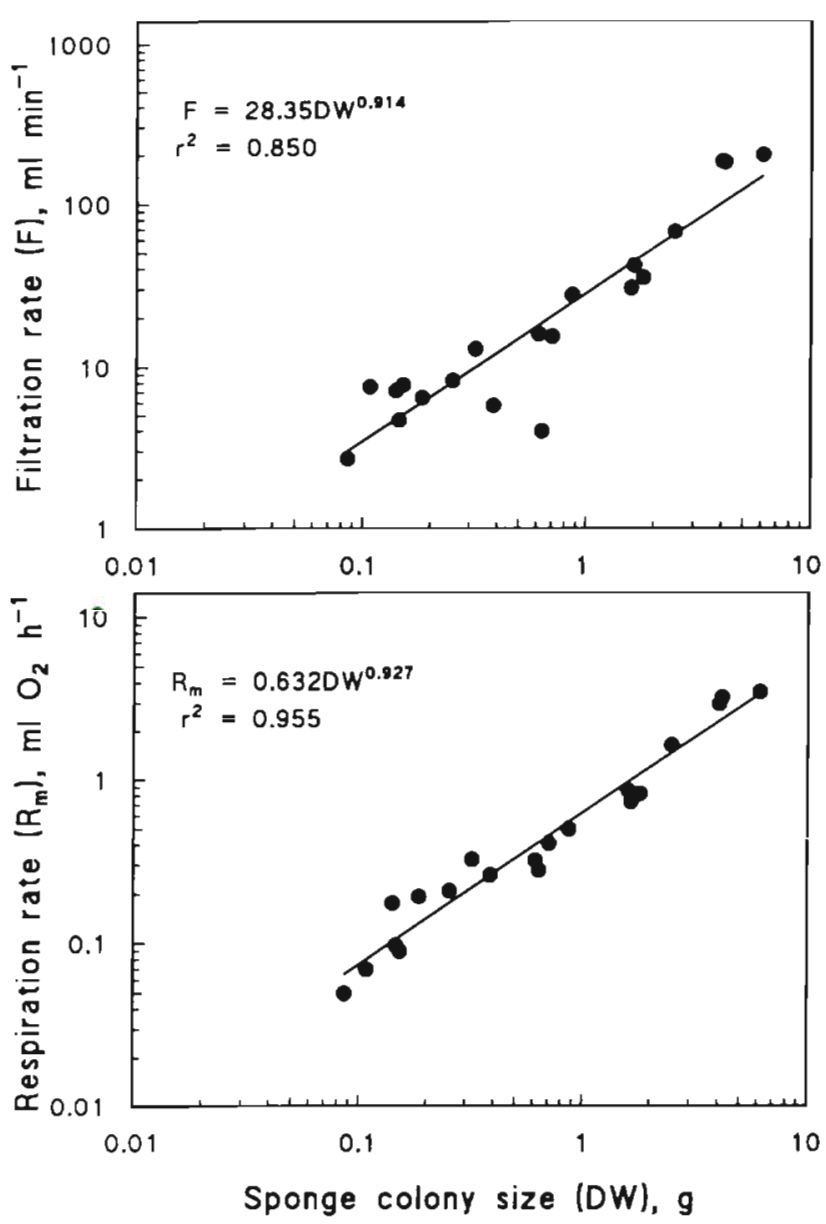

Fig. 2. Halichondria panicea. Filtration rate and maintenance respiration rate as functions of sponge colony size. Regression lines and their equations are shown

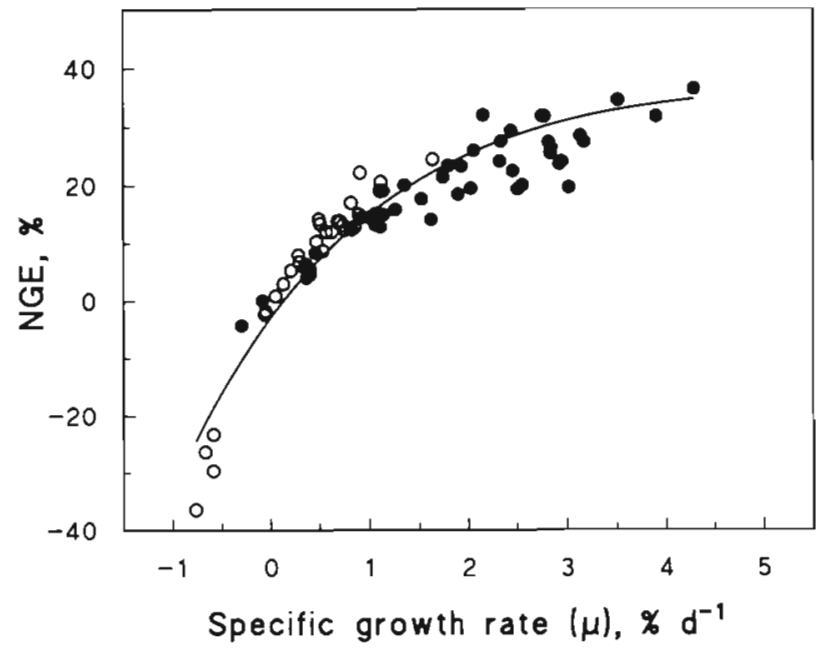

Fig. 3. Halichondria panicea. Net growth efficiency (NGE) as a function of specific growth rate $(\mu)$ of sponge colonies in laboratory $(0)$ and field experiments $(\bullet)$. Curve is fitted by nonlinear regression analysis

tionship between the specific respiration rate $\left(R_{\mathrm{S}}\right)$ and specific growth rate $(\mu)$ may be expressed by this linear function, where $n$ is the slope of the regression line and $a$ is the specific respiration rate at zero growth rate. As $n$ expresses the energy cost per unit of growth (cf. Eq. 3) it is seen that the energy cost of growth $(n)$ in Halichondria panicea constituted $139 \%$ of the biomass production.

Fig. 5 shows that Halichondria panicea fed a constant algal concentration in the laboratory (open symbols) was approaching a steady-state chl a content $(S)$

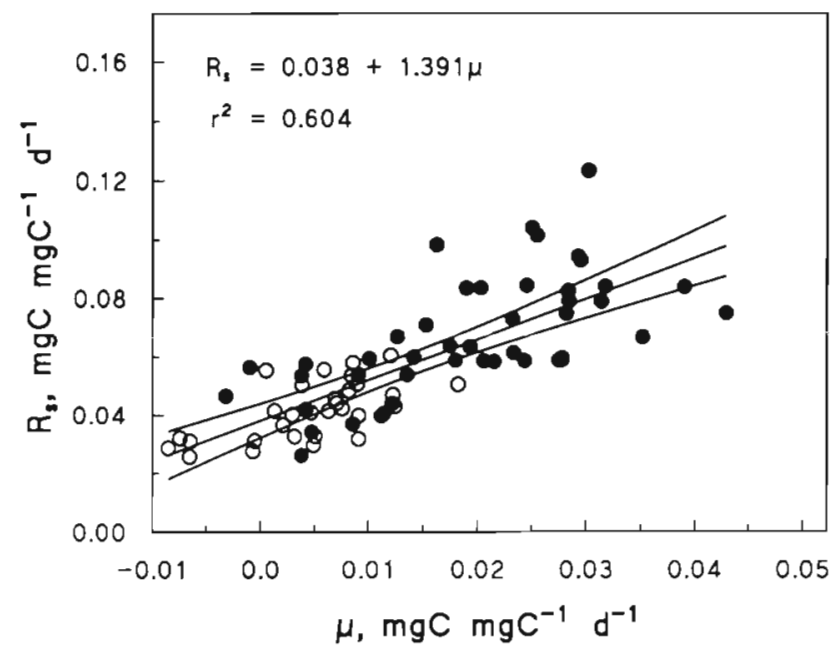

Fig. 4. Halichondria panicea. Specific respiration rate $\left(R_{s}\right)$ as a function of specific growth rate $(\mu)$ of sponge colonies in laboratory $(0)$ and field experiments ( Regression line and its $95 \%$ confidence lines are shown 


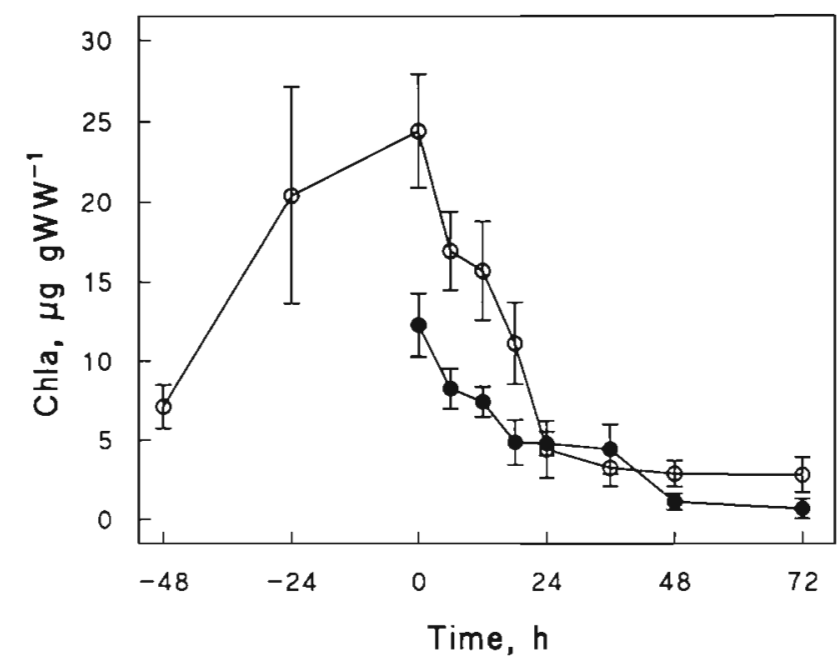

Fig. 5. Halichondria panicea. Decrease of chl a content of sponge colonies transferred to filtered sea water at time 0 . Sponge colonies were transferred either directly from the field (-) or from a laboratory experiment $(0)$ in which the sponges were exposed to suspended algal cells during the preceding $48 \mathrm{~h}$. Mean values $\pm \operatorname{SD}(n=6)$

after $48 \mathrm{~h}$ due to equilibrium between ingestion $(I)$ and digestion of consumed algal cells. After the sponge colonies were transferred to filtered sea water chl a decreased at a constant rate during the first $24 \mathrm{~h}$. A similar decrease was observed in sponges transferred to filtered water directly from the field. From regression analyses it was found that the decomposition constant was $3.3 \% \mathrm{~h}^{-1}\left(\mathrm{r}^{2}=0.964\right)$ in sponges exposed to algal cells $\left(3.58 \mu \mathrm{g} \mathrm{chl} a^{-1}\right)$ in the laboratory and $2.8 \% \mathrm{~h}^{-1}\left(\mathrm{r}^{2}=0.863\right)$ in sponges exposed to natural phytoplankton in the field $\left(1.70 \mu \mathrm{g} \mathrm{chl} \mathrm{a} \mathrm{l}^{-1}\right)$. The estimated filtration rates $\left(F_{\text {esti }}\right.$ cf. Eq. 6$)$ are shown in Table 1 together with relevant variables, as well as the actual measured filtration rate $(F)$ obtained in a laboratory clearance experiment (cf. Eq. 1). The filtration rates of 0.18 to $0.23 \mathrm{I} \mathrm{h}^{-1} \mathrm{~g} \mathrm{WW}^{-1}$ shown in Table 1 are equivalent to 2.5 to $3.0 \mathrm{ml}$ water $\mathrm{min}^{-1}$ (ml sponge tissue $^{-1}$, i.e. near identical to the filtration rates summarized in Table 3 . Thus, there is a satisfactory agreement between the different methods used for determination of the filtration rates.

\section{DISCUSSION}

Irrespective of the scattered data, there seems to be a strong linear relationship between specific growth rate and specific respiration rate in Halichondria panicea (Fig. 4). This increase of the specific respiration rate in response to growth $(n)$, also termed 'specific dynamic action' (SDA), amounted to $139 \%$ of the biomass production. Thus, SDA constituted a very substantial proportion of the total energy released by respiration in growing sponges. The present value of SDA in $H$. panicea may be compared to those reported for other marine invertebrates: 20 to $26 \%$ of the growth in Nereis diversicolor and $N$. virens (Nielsen et al. 1995), 20\% in the blue mussel Mytilus edulis (Jørgensen 1990), 19\% in the copepod Acartia tonsa (Kiørboe et al. 1985) and $40 \%$ in the sea star Asterias rubens (Vahl 1984). Thus, it seems obvious that sponges may differ from other invertebrates by having exceptionally high energy demands for growth. However, due to their simple structure sponges may be described as colonies composed of mainly choanocytes which are structurally and functionally identical to free-living choanoflagellates. Therefore, it is tempting to suppose that sponges may share properties with choanoflagellates. In these organisms and other heterotrophic microflagellates energy used for maintenance only constitutes a small fraction of the energy required for growth (i.e. macromolecular synthesis). Thus, Fenchel (1982, his Fig. 10) found that a doubling of the specific growth rate in the chrysomonad Ochromonas sp. resulted in a doubling of the specific respiration rate, indicating that the energy cost of growth (SDA) constituted approximately $100 \%$ of the growth. Likewise, Lønsmann Iversen (1987, his Fig. 4) found that a doubling of the specific growth rate of the bacteria Klebsiella pneumoniae caused a near doubling $(1.8 \times)$ of the specific respiration rate. Thus, the high SDA $(>100 \%)$ found for $H$. panicea in the present work may be comprehensible by considering the sponge as a colony of heterotrophic microorganisms.

The maximum specific growth rate of $2.8 \% \mathrm{~d}^{-1}$ measured in this study is in the range of specific growth rates of 1 to $5.8 \% \mathrm{~d}^{-1}$ found by others (Table 2 ).

Table 1. Halichondria panicea. Chlorophyll a (chl a) content (S), decomposition constant $(r)$, ingestion rate (I), estimated filtration rate $\left(F_{\text {est }}\right)$ and actual measured filtration rate $(F)$ at known algal concentrations in the laboratory and in the field

\begin{tabular}{|c|c|c|c|c|c|c|}
\hline & $\begin{array}{l}\text { Algal conc. } \\
\left(\mu g \text { chl } a 1^{-1}\right)\end{array}$ & $\begin{array}{c}S \\
\left(\mu \mathrm{g} \mathrm{chl} \operatorname{g~} W W^{-1}\right)\end{array}$ & $\begin{array}{c}r \\
\left(\% \mathrm{~h}^{-1}\right)\end{array}$ & $\left(\mu \mathrm{g} \operatorname{chl} a \mathrm{~h}^{-1} \mathrm{gWW}^{-1}\right)$ & $\begin{array}{c}F_{\mathrm{est}} \\
\left(\mathrm{l} \mathrm{h}^{-1} \mathrm{gWW}^{-1}\right)\end{array}$ & $\begin{array}{c}F \\
\left(1 \mathrm{~h}^{-1} \mathrm{gWW}^{-1}\right)\end{array}$ \\
\hline Lab. & $3.58 \pm 0.37$ & $23.9 \pm 2.8$ & 3.3 & 0.79 & 0.22 & $0.23 \pm 0.03$ \\
\hline Field & $1.70 \pm 0.14$ & $10.7 \pm 0.5$ & 2.8 & 0.30 & 0.18 & - \\
\hline
\end{tabular}


Table 2. Specific growth rates $(\mu)$ measured in different sponge species in the field

\begin{tabular}{|lcl|}
\hline Species & $\begin{array}{c}\mu \\
\left(\% \mathrm{~d}^{-1}\right)\end{array}$ & Source \\
\hline Haliclona permollis & 1.0 & Elvin (1976) \\
Aplysilla rosea & 1.3 & Ayling (1983) \\
Spongilla lacustris & 5.8 & Frost \& Williamson (1980) \\
Halichondria sp. & 3.3 & Fell \& Lewandrowski (1981) \\
Halichondria panicea & 1.7 & Barthel (1986) \\
Halichondria panicea & 1.6 & Barthel (1989) \\
Halichondria panicea & 2.8 & This study \\
\hline
\end{tabular}

The specific filtration and respiration rates of Halichondria panicea measured in the present work are in fairly good agreement with most of the earlier measurements in sponges (Table 3 ). It is remarkable that the slope of the regression lines in Fig. 2 is approximately 1 . Usually, the respiration rate tends to be proportional to the $3 / 4$ power of weight (Fenchel 1987 ), but in sponges linearity is expected in view of the fact that they in principle grow simply by increasing their number of water-pumping choanocytes.

Table 3. Specific filtration rates $\left(F_{s}\right)$ and respiration rates $\left(R_{s}\right)$ measured at different temperatures (Temp) in different sponge species

\begin{tabular}{|c|c|c|c|c|}
\hline Species & $\begin{array}{l}\text { Temp } \\
\left({ }^{\circ} \mathrm{C}\right)\end{array}$ & $\begin{array}{c}F_{s} \\
\left.(\mathrm{ml} \mathrm{min})^{-1}\right)\end{array}$ & $\begin{array}{c}R_{\mathrm{s}} \\
\left(\mathrm{ml} \mathrm{O} \mathrm{h}^{-1}\right)\end{array}$ & Source \\
\hline Mycalesp. & - & $14.4 \mathrm{ml}^{-1}$ & $0.044 \mathrm{ml}^{-1}$ & Reiswig (1974) \\
\hline Verongia gigantea & - & $4.6 \mathrm{ml}^{-1}$ & $0.068 \mathrm{ml}^{-1}$ & Reiswig (1974) \\
\hline Verongia fistularis & 27 & $7.4 \mathrm{ml}^{-1}$ & $0.046 \mathrm{ml}^{-1}$ & Reiswig (1981) \\
\hline Tethya crypta & - & $7.5 \mathrm{ml}^{-1}$ & $0.020 \mathrm{ml}^{-1}$ & Reiswig (1974) \\
\hline Suberites carnosus & 10 & - & $0.79 \mathrm{~g} \mathrm{DW}^{-1}$ & Cotter (1978) \\
\hline Sycon ciliatum & 12 & - & $0.79 \mathrm{~g} \mathrm{DW}^{-1}$ & Cotter (1978) \\
\hline Spongilla lacustris & 27 & $53.0 \mathrm{~g} \mathrm{DW}^{-1}$ & - & Frost $(1978)$ \\
\hline Spongilla lacustris & 20 & - & $0.68 \mathrm{~g} \mathrm{DW}^{-1}$ & Karchenko \& Lyashenko (1986) \\
\hline Haliclona permollis & - & $7.9 \mathrm{ml}^{-1}$ & - & Reiswig (1975) \\
\hline Haliclona anonyma & 12 & $93.4 \mathrm{~g} \mathrm{DW}^{-1}$ & - & Stuart \& Klumpp (1984) \\
\hline Haliclona urceolus & 12 & $31.0 \mathrm{~g} \mathrm{DW}^{-1}$ & - & Riisgård et al. (1993) \\
\hline Halichondria panicea & - & $1.1 \mathrm{mg} \mathrm{N}^{-1}$ & - & Jorgensen (1949) \\
\hline Halichondria panicea & 14 & - & $0.68 \mathrm{~g} \mathrm{AFDW}^{-1}$ & Barthel (1988) \\
\hline Halichondria panicea & 12 & $27.0 \mathrm{~g} \mathrm{DW}^{-1}$ & - & Riisgård et al. (1993) \\
\hline Halichondria panicea & 14 & $28.4 \mathrm{~g} \mathrm{DW}^{-1}$ & $0.63 \mathrm{~g} \mathrm{DW}^{-1}$ & This study, cf. Fig. 2 \\
\hline Halichondria panicea & 14 & $2.0 \mathrm{ml}^{-1}$ & $0.044 \mathrm{ml}^{-1}$ & This study \\
\hline Halichondria panicea & 14 & $0.9 \mathrm{mg} \mathrm{N}^{-1}$ & $1.84 \mathrm{~g} \mathrm{AFDW}^{-1}$ & This study \\
\hline
\end{tabular}

Table 4. Water processing capacities expressed as maximum volumes of water filtered $\left(F\right.$, I) per $\mathrm{ml} \mathrm{O}_{2}$ consumed $(R)$ in various groups of marine invertebrate suspension feeders measured at minimum algal concentrations

\begin{tabular}{|c|c|c|}
\hline $\begin{array}{l}\text { Taxonomic group } \\
\text { Species }\end{array}$ & $\begin{array}{c}F / R \\
\left(1 \mathrm{ml}^{-1} \mathrm{O}_{2}\right)\end{array}$ & Source \\
\hline \multicolumn{3}{|l|}{ Polychaetes } \\
\hline Sabella penicillus & 354 & Riisgård \& Ivarsson (1990) \\
\hline Chaetopterus variopedatus & 50 & Riisgård (1989) \\
\hline Nereis diversicolor & 40 & Riisgård (1991) \\
\hline \multicolumn{3}{|l|}{ Bivalves } \\
\hline Mytilus edulis & 15 to 50 & Riisgård et al. (1980) \\
\hline \multicolumn{3}{|l|}{ Ascidians } \\
\hline Ciona intestinalis & 82 & Petersen et al. (1995) \\
\hline Ciona intestinalis & 13 & Jorgensen (1955) \\
\hline \multicolumn{3}{|l|}{ Copepods } \\
\hline Acartia tonsa & 37 & Kiørboe et al. (1985) \\
\hline \multicolumn{3}{|l|}{ Sponges } \\
\hline Mycale sp & 19.6 & Reiswig (1974) \\
\hline Verongia gigantea & 4.1 & Reiswig (1974) \\
\hline Verongia fistularis & 9.7 & Reiswig (1974) \\
\hline Tethya crypta & 22.8 & Reiswig $\{1974\}$ \\
\hline Halichondria panicea & 2.7 & This study \\
\hline
\end{tabular}

The food content in sea water necessary to meet the metabolic demand of Halichondria panicea can be determined if there is a constant ratio between the volume of water filtered and the amount of $\mathrm{O}_{2}$ consumed by the sponge colony. The specific filtration and respiration rates in the present work were $1.70 \mathrm{I} \mathrm{h}^{-1} \mathrm{~g} \mathrm{DW}^{-1}$ and $0.63 \mathrm{ml} \mathrm{O}_{2} \mathrm{~h}^{-1} \mathrm{~g} \mathrm{DW}^{-1}$, respectively (Fig. 2). The volume of water filtered per $\mathrm{ml} \mathrm{O}_{2}$ consumed was therefore $1.70 / 0.63=2.7 \mathrm{l} \mathrm{ml} \mathrm{m}^{-1} \mathrm{O}_{2}$ which is low compared to other sponges and suspension-feeding invertebrates (see Table 4). The generally higher filtration effectiveness found in tropical demosponges by Reiswig (1974, 1981) was mainly due to a higher specific filtration rate (Table 3 ). This brings the importance of adaptation to the habitat into focus. Referring to Reiswig (1974) 
the available food content for the highly effective Tethya crypta $\left(F / R=22.8 \mathrm{l}\right.$ water $\mathrm{ml}^{-1} \mathrm{O}_{2}$; Table 4) was $0.04 \mathrm{mg}$ particulate organic carbon (POC) $\mathrm{l}^{-1}$ which is $5 \times$ lower than found to be available for $H$. panicea in the present work (see below). Sponges are the only metazoan group which retain very small particles $(0.1$ to $1 \mu \mathrm{m}$ ) (Reiswig 1975) which should be recalled when comparing the generally low $F / R$-values for sponges with other invertebrate filter-feeders (Table 4). A similar example has previously been demonstrated in suspension-feeding ciliates by Fenchel (1980) who found that species specialized to smaller food particles $(0.2$ to $1 \mu \mathrm{m})$ filtered 0.9 to $5 \mathrm{l}$ of water per $\mathrm{ml} \mathrm{O}_{2}$ consumed. In comparison ciliate species feeding on larger particles ( $>1$ to $5 \mu \mathrm{m}$ ) filtered 17 to 7101 per $\mathrm{ml} \mathrm{O}_{2}$ consumed.

To balance the maintenance energy requirement of Halichondria panicea the food energy in suspended particles $(0.1$ to $40 \mu \mathrm{m})$ in $2.7 \mathrm{l}$ sea water must at least be equivalent to $1 \mathrm{ml} \mathrm{O}_{2}$ or $0.46 \mathrm{mg} \mathrm{C}$ implying that POC should be above $0.46 / 2.7=0.17 \mathrm{mg} \mathrm{C} \mathrm{l}^{-1}$. The total energy demand for growth of $H$. panicea with a

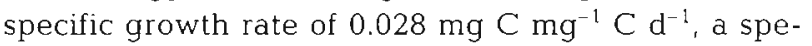
cific respiration rate of $0.0769 \mathrm{mg} \mathrm{C} \mathrm{mg}^{-1} \mathrm{C} \mathrm{d}^{-1}$ and a specific filtration rate of $28.35 \mathrm{ml} \mathrm{min}^{-1} \mathrm{~g} \mathrm{DW}^{-1}=$ $0.287 \mathrm{l} \mathrm{d}^{-1} \mathrm{mg}^{-1} \mathrm{C}$ (Table 2, Figs. $3 \& 4$ ) requires a minimum carbon content (represented as accessible food particles in the water) of $0.0769 / 0.287=0.277 \mathrm{mg}$ $\mathrm{C}^{-1}$. During the field growth experiment the chl a content in phytoplankton smaller than the ostia diameter of approximately $40 \mu \mathrm{m}$ (assuming no uptake of food particles $>40 \mu \mathrm{m}$ ) was measured to be $2.51 \pm$

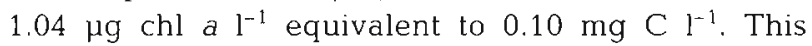
implies that $H$. panicea was unable to cover its carbon requirement on a sole diet of phytoplankton. Larger particles retained on the sponge surface may, however, be a possible food source as mentioned by Simpson (1984). Referring to Fenchel (1984) the amount of carbon represented by free-living bacteria in near shore waters lies in the range of 1 to $3 \times 10^{9}$ cells $\mathrm{I}^{-1}$

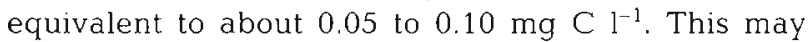
increase the maximum carbon content accessible to the sponge to $0.20 \mathrm{mg} \mathrm{C} \mathrm{l}^{-1}$. However, this is still slightly below the requirement and the deficit may therefore, as suggested by Reiswig (1971), be covered by the uptake of dissolved organic matter.

Considering the uncertainties of the above considerations it may be concluded that the coherence of the measured filtration and respiration rates as related to the actual growth rate and available suspended food particles in sea water is satisfactory. This implies that sponges, despite their relatively low water pumping capacity, may compete well with metazoans with higher filtration rates by means of their unique ability to retain food particles down to $0.1 \mu \mathrm{m}$.
Acknowledgements. Prof. C. Barker Jørgensen, Dr J. J. Lønsmann Iversen and $\mathrm{N}$. Eriksen are greatly acknowledged for their critical review of the manuscript.

\section{LITERATURE CITED}

Arvola L (1981) Spectrophotometric determination of chlorophyll $a$ and phaeopigments in ethanol extractions. Ann Bot Fenn 18:221-227

Ayling AL (1983) Growth and regeneration rates in thinly encrusting demospongiae from temperate waters. Biol Bull 165:343-352

Barnes RD (1987) Invertebrate zoology. Saunders College Publishing, New York, p 71-91

Barthel D (1986) On the ecophysiology of the sponge Halichondria panicea in Kiel Bight. I. Substrate specificity, growth and reproduction. Mar Ecol Prog Ser 32:291-298

Barthel D (1988) On the ecophysiology of the sponge Halichondria panicea in Kiel Bight. Il. Biomass, production energy budget and integration in environmental processes. Mar Ecol Prog Ser 43:87-93

Barthel D (1989) Growth of the sponge Halichondria panicea in the North Sea habitat. In: Klekowski RZ, StyczynskaJurewicz E, Falkowski L (eds) Proc 21st Eur mar biol Symp. Ossolineum, Gdansk, p 23-30

Bergquist PR (1978) Sponges. University of California, Berkeley, p $27-41$

Cotter AJR (1978) Re-investigation of size, axial gradients and light as factors affecting the respiration of certain marine sponges Comp Biochem Physiol 60:117-122

Elvin DW (1976) Seasonal growth and reproduction of an intertidal sponge, Haliclona permollis (Bowerbank). Biol Bull 151:108-125

Fell PE, Lewandrowski KB (1981) Population dynamics of the estuarine sponge, Halichondria sp., within a New England eelgrass community. J exp mar Biol Ecol 55:49-63

Fenchel T (1980) Suspension feeding in ciliated protozoa: feeding rates and their ecological significance. Microb Ecol 6:13-25

Fenchel T (1982) Ecology of heterotrophic microflagellates. II Bioenergetics and growth. Mar Ecol Prog Ser 8:225-231

Fenchel T (1984) Suspended marine bacteria as a food source. Plenum Press, New York

Fenchel T (1987) Ecology - potentials and limitations. In: Kinne $O$ (ed) Excellence in ecology. Ecology Institute, Oldendorf/Luhe, p 137-146

Frost T (1978) In situ measurements of clearance rates for the freshwater sponge Spongilla lacustris. Limnol Oceanogr 23:1034-1039

Frost TM, Williamson CE (1980) In situ determination of the effect of symbiotic algae on the growth of the freshwater sponge Spongilla lacustris. Ecology 6:1361-1370

Jørgensen CB (1949) Feeding-rates of sponges lamellibranchs and ascidians. Nature 163:912

Jørgensen CB (1955) Quantitative aspects of filter-feeding in invertebrates. Biol Rev 30:391-454

Jorgensen CB (1990) Bivalve filter feeding: hydrodynamics, bioenergetics, physiology and ecology. Olsen \& Olsen, Fredensborg

Karchenko TA, Lyashenko AV (1986) Oxygen consumption of fresh-water sponges. Hydrobiol J 22:99-102

Killian EF (1952) Wasserströmung und Nahrungsaufnahme beim Süsswasserschwamm Ephydatia fluviatilis. $\mathrm{Z}$ vgl Physiol 34:407-447

Kiørboe T, Møhlenberg F, Hamburger K (1985) Bioenergetics of the planktonic copepod Acartia tonsa: relation between 
feeding, egg production and respiration, and composition of specific dynamic action. Mar Ecol Prog Ser 26:85-97

Kiørboe T, Munk P, Richardson K (1987) Respiration and growth of the larval herring Clupea harengus: relation between specific dynamic action and growth efficiency. Mar Ecol Prog Ser 40:1-10

Larsen PS, Riisgård HU (1994) The sponge pump. J theor Biol 168:53-63

Lonsmann Iversen JJ (1987) The $\mathrm{pH}$ mediated effects of initial glucose concentration on the transitory occurrence of extracellular metabolites, gas exchange and growth yields of aerobic batch cultures of Klebsiella pneumoniae. Biotechnol Bioeng 30:352-362

Nielsen AM, Eriksen NT, Iversen JJL, Riisgård HU (1995) Feeding, growth and respiration in the polychaetes Nereis diverscolor (facultative filter-feeder) and $N$. virens (omnivorous) - a comparative study. Mar Ecol Prog Ser 125: $149-158$

Petersen JK, Schou O, Thor P (1995) Growth and energetics in the ascidian Ciona intestinalis (L.). Mar Ecol Prog Ser 120: $175-184$

Reiswig HM (1971) Particle feeding in natural populations of three marine demosponges. Biol Bull 141:191-226

Reiswig HM (1974) Water transport, respiration and energetics of three tropical marine sponges. J exp mar Biol Ecol $14: 231-249$

Reiswig HM (1975) Bacteria as food for temperate-water marine sponges. Can J Zool 53:582-589

This article was submitted to the editor
Reiswig HM (1981) Partial carbon and energy budgets of the bacteriosponge Verongia fistularis (Porifera: Demospongia) in Barbados. PSZN I: Mar Ecol 2:273-293

Riisgård HU (1989) Properties and energy cost of the muscular piston pump in the suspension feeding polychaete Chaetopterus variopedatus. Mar Ecol Prog Ser 56:157-168

Riisgărd HU (1991) Suspension feeding in the polychaete Nereis diversicolor. Mar Ecol Prog Ser 70:29-37

Riisgård HU, Ivarsson NM (1990) The crown-filament pump of the suspension-feeding polychaete Sabella penicillus: filtration, effects of temperature, and energy cost. Mar Ecol Prog Ser 62:249-257

Riisgård HU, Randløv A, Kristensen PS (1980) Rates of water processing, oxygen consumption and effiency of particle retention in veligers and post-metamorphic Mytilus edulis. Ophelia 19:37-47

Riisgărd $\mathrm{HU}$, Thomassen $\mathrm{S}$, Jakobsen $\mathrm{H}$, Weeks $\mathrm{JM}$, Larsen PS (1993) Suspension feeding in marine sponges Halichondria panicea and Haliclona urceolus: effects of temperature on filtration rate and energy cost of pumping. Mar Ecol Prog Ser 96:177-188

Simpson TL (1984) The cell biology of sponges. SpringerVerlag, New York

Stuart V, Klumpp DW (1984) Evidence for food-resource partitioning by kelpbed filter feeders. Mar Ecol Prog Ser 16:27-37

Vahl O (1984) The relationship between specific dynamic action (SDA) and growth in the common starfish. Asterias rubens L. Oecologia 61:122-125

Manuscript first received: March 16, 1995

Revised version accepted: May 29, 1995 